\title{
Increased Fat and Skeletal Muscle $\beta$-Adrenergic Receptors but Unaltered Metabolic and Hemodynamic Sensitivity to Epinephrine In Vivo in Experimental Human Thyrotoxicosis
}

\author{
Stephen B. Liggett, Suresh D. Shah, and Philip E. Cryer \\ Metabolism and Pulmonary Divisions of the Department of Medicine, and the General Clinical Research Center and Diabetes \\ Research and Training Center, Washington University School of Medicine, St. Louis, Missouri 63110
}

\begin{abstract}
Based largely on evidence of increased target tissue $\beta$-adrenergic receptor densities and responsiveness in animal and, to a lesser extent, human tissues, it is often assumed that thyroid hormone excess results in increased sensitivity to catecholamines in vivo, thus explaining several clinical manifestations of thyrotoxicosis. To test the hypothesis that thyrotoxicosis results in increased target tissue $\beta$-adrenergic receptor densities and correspondingly increased metabolic and hemodynamic sensitivity to epinephrine in vivo, we measured these in 10 normal humans before and after administration of triiodothyronine (100 $\mu \mathrm{g}$ daily) for $10 \mathrm{~d}$. Thyrotoxicosis increased $\beta$-adrenergic receptor densities in fat $(\sim 60 \%)$ and skeletal muscle $(\sim 30 \%)$. Despite increments in $\beta$-adrenergic receptor densities in these and probably other target tissues, metabolic and hemodynamic sensitivity to epinephrine in vivo was unaltered. An apparently adaptive increase in insulin secretion plausibly explains normal glycemic, glycogenolytic/glycolytic, lipolytic, and ketogenic sensitivity to epinephrine in the thyrotoxic state. In view of this striking homeostatic efficiency of the intact individual, the finding of altered adrenergic receptors, even in relevant target tissues, should not be extrapolated to altered sensitivity to catecholamines in vivo in the absence of direct testing of that hypothesis. With respect to the clinical issue, these data suggest that increased sensitivity to catecholamines does not explain clinical manifestations of thyrotoxicosis in humans.

\section{Introduction}

Several manifestations of thyrotoxicosis resemble those of catecholamine excess and are ameliorated by administration of a $\beta$-adrenergic antagonist (1). If these are catecholamine mediated, they must be the result of increased sensitivity to catecholamines since sympathochromaffin catecholamine release is not increased $(2,3)$. In addition to a body of evidence from animal studies (reviewed in references 4 and 5), several in vitro studies using tissues from thyrotoxic humans are consistent with this possibility. Increased mononuclear leukocyte
\end{abstract}

Address correspondence to Dr. Philip E. Cryer, Metabolism Division (Box 8127), Washington University School of Medicine, 660 South Euclid Avenue, St. Louis, MO 63110.

Received for publication 27 May 1988 and in revised form 12 September 1988.

J. Clin. Invest.

(C) The American Society for Clinical Investigation, Inc.

$0021-9738 / 89 / 03 / 0803 / 07 \quad \$ 2.00$

Volume 83, March 1989, 803-809 $\beta$-adrenergic receptor densities (5-7) and adenylate cyclase responses to isoproterenol (7) have been reported, although these findings have not been universal (8-10). Similarly, there are reports of increased $\beta$-adrenergic receptor densities and cAMP and lipolytic responses to agonists of fat cells removed from thyrotoxic humans $(11,12)$. The impact of such thyroid hormone-induced changes in catecholamine target tissues on sensitivity to catecholamines in vivo is unclear. Seemingly wellcontrolled studies of thyrotoxic humans have not disclosed increased hemodynamic sensitivity to infused catecholamines $(13,14)$ although increased responses have been noted in other studies $(15,16)$. With respect to metabolic actions, increased plasma FFA responses to catecholamines were noted in some, but not all, of a small number of thyrotoxic patients (17). Increased metabolic rate responses to epinephrine have been reported (16). However, plasma glucose responses to epinephrine have been reported to be decreased (18). To our knowledge plasma catecholamine concentration-response curves have not been used to measure sensitivity to catecholamines in vivo in thyrotoxic humans, nor have in vivo sensitivity and $\beta$-adrenergic receptor status of target tissues been assessed in the same individuals.

The apparent contradiction between the in vitro and in vivo findings just summarized could be reconciled if increased target tissue sensitivity to catecholamines induced by thyroid hormone excess, demonstrable in vitro, were offset by adaptive changes in physiologic regulatory systems in the intact individual. To test this hypothesis we assessed the impact of experimental thyrotoxicosis on $\beta$-adrenergic receptors and adenylate cyclase in two catecholamine target tissues, fat and skeletal muscle, studied in vitro, and on metabolic and hemodynamic responses to epinephrine in vivo in the same human subjects.

Fat and muscle were selected for in vitro study because they play important roles in the lipolytic and ketogenic responses and the glycemic and glycogenolytic/glycolytic responses to epinephrine, respectively, in vivo $(19,20)$, and because it is feasible to biopsy these in humans. The direct actions of epinephrine to increase glucose production and limit glucose use are largely, perhaps exclusively, mediated through $\beta_{2}$-adrenergic mechanisms in humans. The major indirect hyperglycemic action is $\alpha_{2}$-adrenergic limitation of insulin secretion. Epinephrine also stimulates lipolysis, ketogenesis, and glycogenolysis (and in muscle, glycolysis), largely through $\beta$ adrenergic mechanisms (19). Although both $\beta_{1}$-adrenergic receptors that mediate an increase in lipolysis and $\alpha_{2}$-adrenergic receptors that mediate a decrease in lipolysis are present on fat cells, the net effect of epinephrine is to increase lipolysis (21). Insulin, on the other hand, suppresses all of these metabolic processes. Acting through $\beta$-adrenergic receptors, epinephrine also increases heart rate and widens pulse pressure. 


\section{Methods}

Study design. 10 healthy subjects ( 2 females, 8 males ages $22-33 \mathrm{yr}$ ) of normal height and weight participated in two identical study sessions. The control study was performed while the subjects were taking no medications and the thyrotoxic study was performed after the subjects had taken oral triiodothyronine ( $100 \mu \mathrm{g} / \mathrm{d}$ in four divided doses) for 10 d. After an overnight fast the subjects rested supine for $\mathbf{3 0}$ min and then, under local anesthesia, an open fat biopsy was performed, followed by a percutaneous skeletal muscle needle biopsy. The subjects then had two intravenous lines inserted (one for sampling and one for epinephrine infusion) and rested for $45 \mathrm{~min}$, at which time a 3.5-h epinephrine infusion study was begun. These studies were approved by the Washington University School of Medicine Human Studies Committee and all subjects gave written informed consent.

Fat cells. Fat (0.75-1.0 g wet wt) was obtained from $1-\mathrm{cm}$ incisions in the upper gluteal region after four-quadrant local anesthesia was established with $0.5 \%$ bupivicaine. At no time was the anesthetic injected directly into the fat to be biopsied. The duration of anesthesia for both fat and skeletal muscle biopsies was $>8 \mathrm{~h}$; thus, the subjects experienced no pain from the biopsy sites during the subsequent epinephrine infusions. Fat cells were isolated by a method similar to that of Rodbell (22). The common buffer for fat cell studies was KrebsRinger phosphate (128 mM NaCl, $1.4 \mathrm{mM} \mathrm{MgSO}_{4}, 1.4 \mathrm{mM} \mathrm{CaCl}_{2}, 5.2$ $\mathrm{mM} \mathrm{KCl}, 10 \mathrm{mM} \mathrm{Na}_{2} \mathrm{HPO}_{4}$, and $0.2 \mathrm{~g} / 100 \mathrm{ml}$ dextrose) (KRP). ${ }^{1}$ Fat was minced and placed in $5.0 \mathrm{ml}$ of KRP supplemented with $3.0 \mathrm{~g} / 100$ $\mathrm{ml} \mathrm{BSA}$ and $0.5 \mathrm{mg} / \mathrm{ml}$ crude collagenase, shaken in a rotating bath at 50 cycles $/ \mathrm{s}$ for $60 \mathrm{~min}$ at $37^{\circ} \mathrm{C}$, and the cells filtered through $300-\mu \mathrm{m}$ nylon mesh. Collagenase from the same pretested batch was used in all experiments. The fat cells were washed in assay buffer (collagenase-free KRP with $0.5 \mathrm{~g} / 100 \mathrm{ml} \mathrm{BSA}$ ) three times by resuspension and 10 -s centrifugations. The typical final suspension was $8 \mathrm{ml}$ with a concentration of $\sim 3 \times 10^{5}$ cells $/ \mathrm{ml}$. Portions of this suspension were then used for $\beta$-adrenergic receptor binding studies and cAMP studies described below. Cell number was determined from DNA analysis by the fluorometric bisbenzimide method (23) using calf thymus DNA for standards and assuming $5 \mathrm{pg}$ of DNA/cell.

Skeletal muscle membranes. After $0.5 \%$ bupivicaine subcutaneous anesthesia a Bergstrom biopsy needle (Depuy Manufacturing, Warsaw, IN) was used to obtain $\sim 200 \mathrm{mg}$ of skeletal muscle from the lateral gastrocnemius muscle. The method of biopsy and preparation of skeletal muscle membranes was as described recently (24). The muscle was frozen in liquid nitrogen and stored at $-70^{\circ} \mathrm{C}$ until processing, at which time homogenization with a polytron (Brinkmann Instruments, Inc., Westbury, NY) in cold $10 \mathrm{mM}$ Tris/5 mM EDTA buffer was performed. The suspension was filtered once through nylon mesh, washed twice by centrifugation at $45,000 \mathrm{~g}$ for $20 \mathrm{~min}$, and resuspended. The final resuspension was in $75 \mathrm{mM}$ Tris $/ 25 \mathrm{mM} \mathrm{MgCl}, 5$ mM EDTA buffer (skeletal muscle assay buffer). Protein concentration was determined by the method of Bradford using BSA as standards (25).

Receptor binding studies. Both intact fat cell and skeletal muscle membrane $\beta$-adrenergic receptors were studied with $\left[{ }^{125} \mathrm{I}\right]$ pindolol (IPIN) with propranolol $(1 \mu \mathrm{M})$ used to define nonspecific binding. As described by Doyle et al. (26), the specific activity of IPIN was assumed to be constant during decay of ${ }^{125} \mathrm{I}$. The conditions described below provided the appropriate properties for ligand receptor interactions (saturability, reversibility, stereospecificity, rank order potency, and typical kinetics) as determined by preliminary studies. Intact fat cells $\left(\sim 4 \times 10^{4}\right)$ were incubated in assay buffer (final vol $\left.0.5 \mathrm{ml}\right)$ in triplicate with eight concentrations of IPIN (10-500 pM) in the absence or presence of $1 \mu \mathrm{M}$ propranolol for $30 \mathrm{~min}$ at $37^{\circ} \mathrm{C}$. The reaction was terminated by addition of $10 \mathrm{ml}$ ice-cold $154 \mathrm{mM} \mathrm{NaCl}$ and the con-

1. Abbreviations used in this paper: IBMX, 3-isobutyl-1-methylxanthine; IPIN, [ $\left.{ }^{125} \mathrm{I}\right]$ pindolol; KRP, Krebs-Ringer phosphate; MANOVA, multivariate analysis of variance. tents filtered over glass fiber filters (type GF/C; Whatman.Laboratory Products Inc., Clifton, NJ). The tubes and filters were washed with 10 $\mathrm{ml}$ additional $\mathrm{NaCl}$ and the filters counted in a gamma counter at $80 \%$ efficiency. The binding of IPIN to fat cells was similar to that described for [ ${ }^{125}$ I] iodocyanopindolol (11). Nonspecific binding represented 15 and $40 \%$ of total binding at 10 and $500 \mathrm{pM}$ IPIN, respectively. Skeletal muscle membranes $(\sim 100 \mu \mathrm{g})$ were incubated in triplicate with eight concentrations of IPIN (5-300 pM) in a final vol of $0.25 \mathrm{ml}$ with or without $1 \mu \mathrm{M}$ propranolol for $90 \mathrm{~min}$ at $25^{\circ} \mathrm{C}(24)$. GTP $(100 \mu \mathrm{M})$ was included to eliminate retained agonist binding. The tubes and filters were washed with ice-cold skeletal muscle assay buffer in the same manner as described for fat cells, and the filters counted.

cAMP and adenylate cyclase studies. For intact fat cells the accumulation of cAMP was studied by incubating cells in assay buffer with $1 \mathrm{mM}$ ascorbic acid and $0.1-\mathrm{mM}$ concentrations of the phosphodiesterase inhibitors RO-20-1724 and 3-isobutyl-1-methylxanthine (IBMX) in the presence or absence of various agents for $5 \mathrm{~min}$ at $37^{\circ} \mathrm{C}$. The reaction was terminated by addition of perchloric acid, neutralized with potassium bicarbonate, centrifuged, and an aliquot of the supernatant acetylated with acetic anhydride and triethylamine (27). cAMP was measured by RIA using ${ }^{125}$ I-succinyl cAMP by the method of Steiner et al. (28). For assessment of maximal $\beta$-adrenergic receptor-mediated cAMP production cells were incubated with $10 \mu \mathrm{M}$ isoproterenol. For $\alpha$-adrenergic receptor stimulation (which causes an inhibition of adenylate cyclase) cells were incubated with $10 \mu \mathrm{M}$ isoproterenol plus $10 \mu \mathrm{M}$ epinephrine. (Preliminary studies showed that the $\alpha_{2}$-adrenergic antagonist yohimbine blocked this inhibitory effect of epinephrine and that the $\alpha_{2}$-adrenergic agonist clonidine had a similar but less potent inhibitory effect.)

Adenylate cyclase activities of skeletal muscle membranes were assessed by incubating membranes (5-20 $\mu \mathrm{g}$ ) with $0.2 \mathrm{mM}$ ATP, 0.1 mM GTP, $1.0 \mathrm{mM}$ IBMX, $10 \mathrm{mM} \mathrm{MgCl}_{2}, 1.0 \mathrm{mM}$ EDTA, $50 \mathrm{mM}$ Tris, $1.0 \mathrm{mM}$ ascorbic acid, $25 \mathrm{mM}$ phosphocreatine, and $1.0 \mathrm{mg} / \mathrm{ml}$ creatine phosphokinase, in the presence or absence of $10 \mu \mathrm{M}$ isoproterenol for $15 \mathrm{~min}$ at $37^{\circ} \mathrm{C}(24)$. The reaction was stopped by placing the tubes in a boiling water bath for $3 \mathrm{~min}$. cAMP was measured by RIA as described above.

Epinephrine infüsions. After $45 \mathrm{~min}$ of supine rest after the biopsies measurements of blood pressure and heart rate (Dynamap model 1846; Critekon Inc., Tampa, FL) and blood sampling were performed every $10 \mathrm{~min}$ for $210 \mathrm{~min}$. At each time point $10 \mathrm{ml}$ of blood was sampled and aliquotted to appropriate tubes for measurements of epinephrine and norepinephrine by a single isotope derivative (radioenzymatic) method (29), and glucose, FFA, $\beta$-hydroxybutyrate, glycerol, lactate and alanine and insulin, C-peptide, glucagon, cortisol, growth hormone, and pancreatic polypeptide by methods used previously ( 20 , 30). The first $\mathbf{3 0}$ min constituted baseline measurements without epinephrine infusion. Thereafter, epinephrine (diluted in saline with 0.5 $\mathrm{mg} / \mathrm{ml}$ ascorbic acid) was infused by Harvard pump (model 22; Harvard Apparatus Co., Inc., South Natick, MA) over sequential 30-min intervals in doses of $1.4,7,14,28,42$, and $70 \mathrm{ng} / \mathrm{kg}$ per min. The intravenous lines were maintained with infusions of normal saline at a rate that matched blood loss.

Statistical analysis. The receptor densities $\left(B_{\max }\right)$ and apparent dissociation constants $\left(K_{d}\right)$ for fat cell and skeletal muscle membrane $\beta$-adrenergic receptors were obtained by Scatchard analysis (31) of the saturation binding studies described above. Data are presented as the mean \pm SE. Comparisons of control and thyrotoxic receptor properties, cAMP content, or adenylate cyclase activities were performed by paired $t$ tests. For summary purposes epinephrine plasma concentration-response curves are presented as plots of the means \pm SE for a given response vs. the means $\pm \mathrm{SE}$ of the epinephrine concentrations at the end of each 30-min infusion period. Methods described previously (20, 32) were used to determine the presence of differences between control and thyrotoxic concentration-response curves. Individual curves were normalized to baseline (time 0 ) values and then the data were fit to a fourth degree polynomial. The coefficients from these equations were then compared by multivarate analysis of variance (MANOVA) using 
SAS version 6.02 (SAS Institute, Cary, NC). For $t$ tests and MANOVA significance was defined as $P<0.05$.

Chemicals. [ $\left.{ }^{125} \mathrm{I}\right]$ Pindolol $(2,200 \mathrm{Ci} / \mathrm{mmol})$ was purchased from New England Nuclear (Boston, MA) and $\mathrm{Na}^{125}$ I from Amersham Corp. (Arlington Heights, IL). ${ }^{125}$ I-succinyl cAMP (tyrosine methylesther) was made by the method of Steiner et al. (28). (-)Propranolol was a gift from Ayerst Laboratories (New York, NY) and RO-20-1724 was a gift from Hoffman-La Roche (Nutley, NJ). Crude collagenase (204 U/mg, lot No. 67155M) was purchased from Worthington Biochemical Corp. (Freehold, NJ). Triidothyronine was supplied as 25- $\mu$ g tablets (Cytomel; Smith, Kline and French, Philadelphia, PA). All other reagents were purchased from Sigma Chemical Co. (St. Louis, MO).

\section{Results}

Triiodothyronine administration resulted in elevated serum $\mathrm{T}_{3}$ levels ( $126 \pm 11$ to $349 \pm 43 \mathrm{ng} / \mathrm{dl}, P<0.002)$, decreased thyroid-stimulating hormone levels $(1.27 \pm 0.27$ to $0.15 \pm 0.05$ $\mu \mathrm{U} / \mathrm{ml}, P<0.002)$, and decreased serum thyroxine levels $(6.4 \pm 0.4$ to $3.3 \pm 0.3 \mu \mathrm{g} / \mathrm{dl}, P<0.0001)$. Resting heart rate increased $\sim 30 \%(58 \pm 4$ to $75 \pm 4$ beats $/ \mathrm{min}, P<0.02$ ). Baseline plasma catecholamine concentrations were unaltered. Plasma epinephrine levels were $31 \pm 8$ and $37 \pm 12 \mathrm{pg} / \mathrm{ml}$ and norepinephrine levels were $119 \pm 14$ and $131 \pm 17 \mathrm{pg} / \mathrm{ml}$, respectively, before and during triiodothyronine administration.

Thyrotoxicosis was associated with an increase in $\beta$-adrenergic receptor densities in both intact fat cells and skeletal muscle membranes (Fig. 1). Fat cell receptor density increased $\sim 60 \%$, from $6,230 \pm 970$ to $9,920 \pm 1,590$ sites/cell $(P<0.05)$ without a change in IPIN binding affinity $\left(K_{d}=77 \pm 8\right.$ vs. $102 \pm 31 \mathrm{pM})$. Skeletal muscle $\beta$-adrenergic receptor density increased $\sim 30 \%$, from $7.9 \pm 1.0$ to $10.2 \pm 0.9 \mathrm{fmol} / \mathrm{mg}$ protein $(P<0.05)$, with an increase in IPIN binding affinity $\left(K_{\mathrm{d}}\right.$ $=23 \pm 1$ vs. $10 \pm 1 \mathrm{pM}, P<0.0001)$ after thyrotoxicosis. Neither basal ( $47 \pm 10$ vs. $41 \pm 8$ pmol cAMP $/ 10^{7}$ cells) nor $\beta$-adrenergic receptor-mediated maximal stimulation ( $310 \pm 37$ vs. $333 \pm 35$ pmol cAMP $/ 10^{7}$ cells) of fat cell cAMP content was altered by thyrotoxicosis. Basal (336 \pm 53 vs. $452 \pm 90 \mathrm{pmol} \mathrm{cAMP} / \mathrm{mg}$ protein per $15 \mathrm{~min}$ ) and iosproterenol-stimulated (501 $\pm 95 \mathrm{vs}$. $749 \pm 134 \mathrm{pmol} \mathrm{cAMP} / \mathrm{mg}$ protein per $15 \mathrm{~min}$ ) skeletal muscle adenylate cyclase activities were not different statistically. The $\alpha_{2}$-adrenergic-mediated inhibition of cAMP production in fat cells was unchanged ( $74 \pm 10$ vs. $86 \pm 4 \%$ inhibition).

In vivo plasma epinephrine concentration-response curves for FFA, $\beta$-hydroxybutyrate, glucose, and lactate are illustrated in Fig. 2. There were no significant differences in the responses of these to epinephrine during thyrotoxicosis. The epinephrine concentration-response curves for heart rate and blood pressure are shown in Fig. 3. Although baseline heart rates were elevated after thyrotoxicosis, the response to infused epinephrine was the same as in the euthyroid state. Systolic and diastolic blood pressure responses were also unaltered. In contrast, insulin, C-peptide, and pancreatic polypeptide secretory responses to epinephrine were clearly increased $(P:<0.05$, MANOVA) during thyrotoxicosis as depicted in Fig. 4. Glucagon levels were unchanged (Fig. 4). In data not shown the cortisol, growth hormone, alanine, and norepinephrine responses were not altered significantly although plasma norepinephrine appeared to rise to higher levels during epinephrine infusions after triiodothyronine administration. As is apparent from Figs. 2-4, plasma epinephrine concentrations were comparable in the control and triiodothyronine studies.
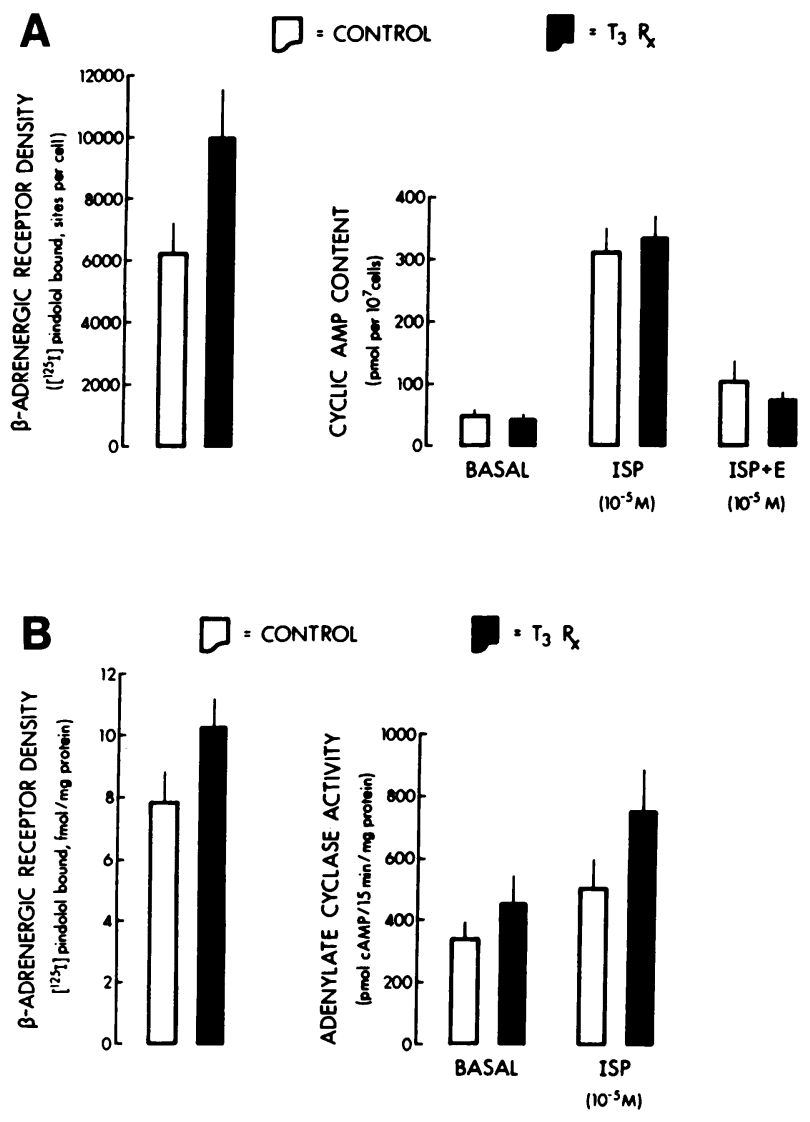

Figure 1. Effects of thyrotoxicosis on fat cell $(A)$ and skeletal muscle $(B) \beta$-adrenergic receptor densities, fat cell basal, isoproterenol (ISP)stimulated, and epinephrine $(E)$ inhibition of ISP-stimulated cAMP contents and basal and ISP-stimulated skeletal muscle adenylate cyclase activities. Control $=$ before and $\mathrm{T}_{3}=$ during triiodothyronineinduced thyrotoxicosis.

\section{Discussion}

To test the hypothesis that thyrotoxicosis results in increased target tissue $\beta$-adrenergic receptor densities and correspondingly increased metabolic and hemodynamic sensitivity to epinephrine in vivo, we measured these in 10 normal humans before and after administration of triiodothyronine $(100 \mu \mathrm{g}$ daily) for $10 \mathrm{~d}$. This dose, administered for only $7 \mathrm{~d}$, was previously shown to result in objective thyrotoxicosis and increased mononuclear leukocyte $\beta$-adrenergic receptor density in a placebo-controlled study (5). It raised serum triiodothyronine concentrations nearly threefold, suppressed serum thyroid-stimulating hormone levels, and increased resting heart rate in the present study. Thyrotoxicosis was associated with significant increments in fat cell and skeletal muscle $\beta$-adrenergic receptor densities averaging $\sim 60$ and $30 \%$, respectively. Basal and maximal isoproterenol-stimulated cAMP contents (fat) and adenylate cyclase activities (muscle) were unaltered by triiodothyronine administration, but sensitivity to agonist was not tested because of limited tissue availability. Thus, the sensitivity of individual tissues to epinephrine may well have been increased.

Since triiodothyronine administration has been shown previously to increase mononuclear leukocyte $\beta$-adrenergic receptor density (5-7), and the latter correlates with myocar- 

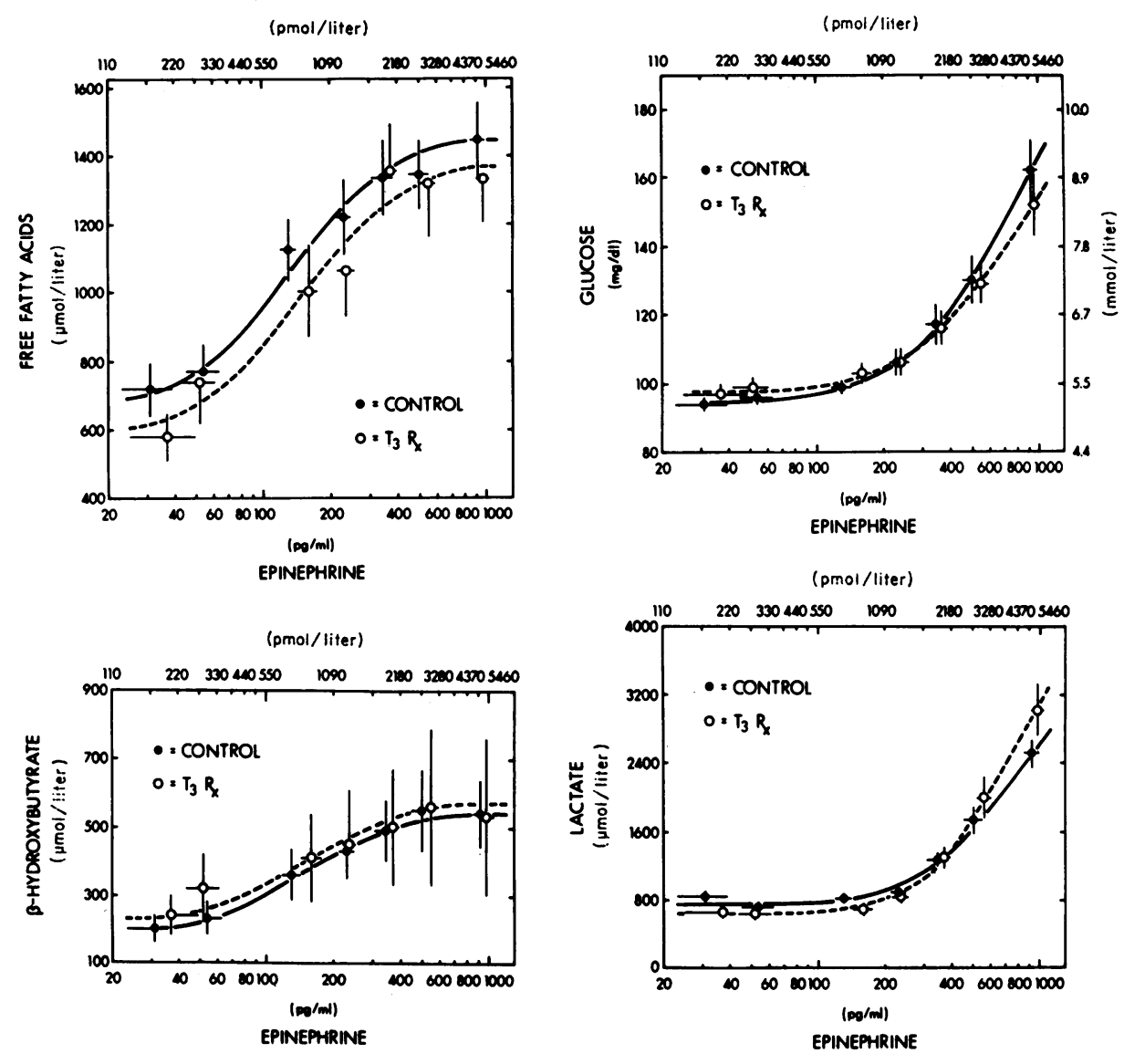

Figure 2. In vivo plasma epinephrine concentration-response curves for FFA, $\beta$-hydroxybutyrate, glucose, and lactate before (control) and during $\left(T_{3} R x\right)$ triiodothyronine-induced thyrotoxicosis.
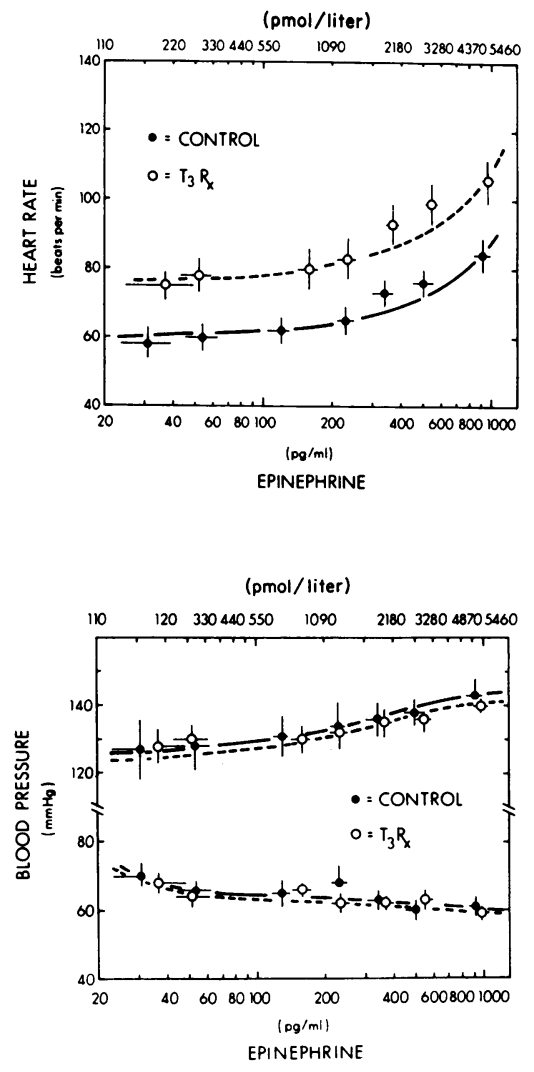

Figure 3. Heart rate and systolic and diastolic blood pressure plasma epinephrine concentration-response curves before (control) and during $\left(T_{3} R x\right)$ triiodothyronine-induced thyrotoxicosis. dial (33) and lung (34) receptor densities, thyroid hormone excess probably resulted in increased $\beta$-adrenergic receptor densities in diverse catecholamine target tissues in addition to fat and skeletal muscle.

Despite these increments in target tissue $\beta$-adrenergic receptor densities, metabolic and hemodynamic responses to epinephrine in vivo were unaltered in the thyrotoxic state. Epinephrine was infused intravenously in six doses that resulted in steady-state plasma epinephrine concentrations that spanned the physiologic range (19) before and during experimental thyrotoxicosis. The epinephrine plasma concentrations were similar on both occasions. Plasma epinephrine concentration-response curves for plasma glucose, blood lactate, serum FFA, and blood $\beta$-hydroxybutyrate concentrations, as well as those for systolic and diastolic blood pressure and heart rate, were virtually identical under both conditions. Complete epinephrine concentration-response curves were obtained for FFA and $\beta$-hydroxybutyrate levels. Neither sensitivity nor responsiveness to epinephrine was altered. Although complete concentration-response curves for the other variables mentioned cannot be constructed in humans, there was no suggestion of increased sensitivity of the changes in these to epinephrine.

Why was sensitivity to epinephrine in vivo unaltered despite increased target tissue $\beta$-adrenergic receptor densities during triiodothyronine administration? One possibility is that the increase in receptor density was not of sufficient magnitude to alter cellular responses to the agonist. Alternatively, 

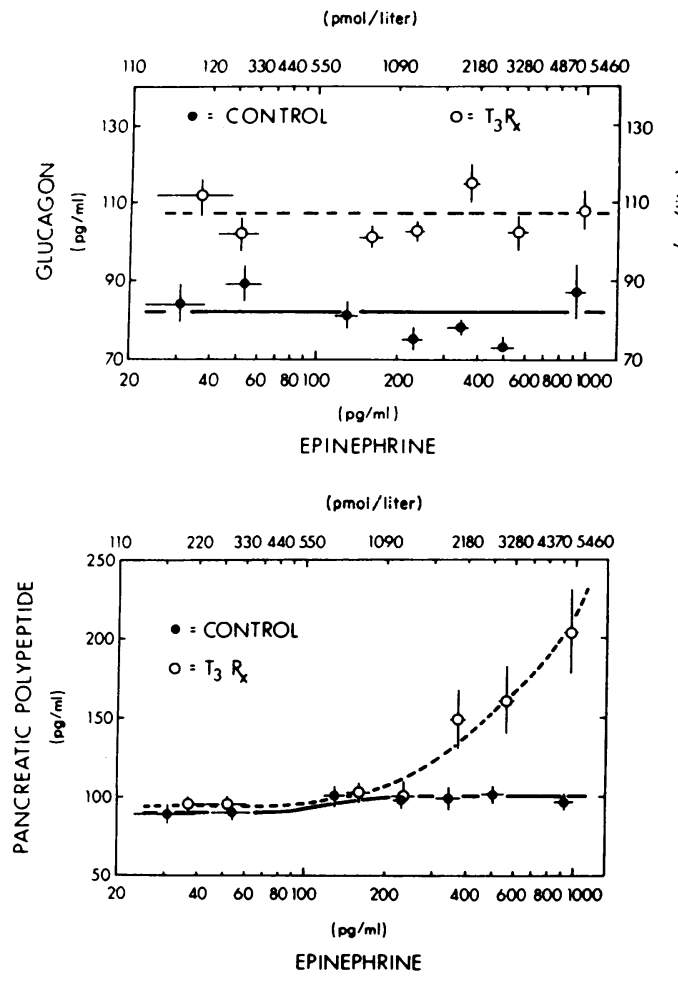

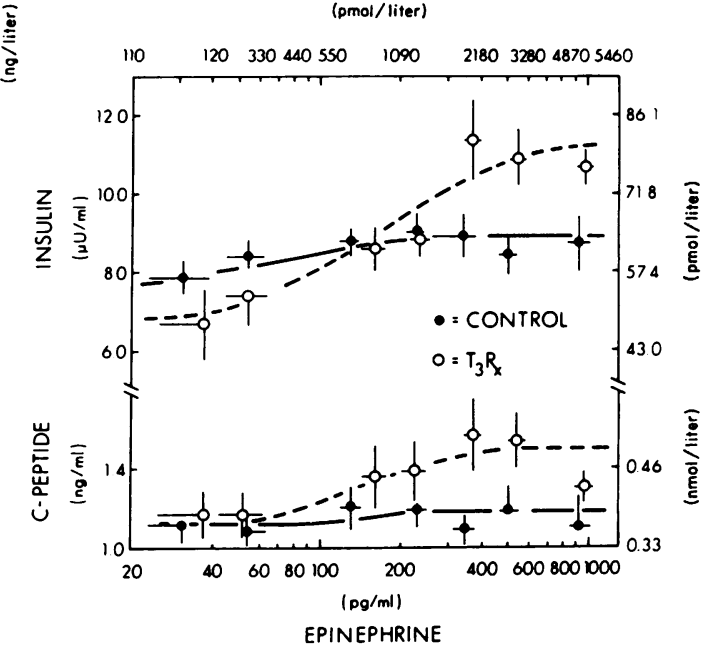

Figure 4. In vivo plasma epinephrine concentration-response curves for glucagon, pancreatic polypeptide, insulin, and C-peptide, before (control) and during $\left(T_{3} R x\right)$ triiodothyronine-induced thyrotoxicosis. The responses for insulin, C-peptide, and pancreatic polypeptide were significantly increased during thyrotoxicosis as assessed by MANOVA. offsetting local (intracellular, autocrine, or paracrine) or systemic regulatory compensation may have occurred. Although we cannot exclude roles for the other possibilities, we suggest that systemic regulatory compensation accounts, at least in part, for these findings based on our in vivo data. The absence of increased glycemic (plasma glucose), glycogenolytic/glycolytic (blood lactate), lipolytic (serum FFA), and ketogenic (blood $\beta$-hydroxybutyrate) sensitivity to epinephrine in vivo despite triiodothyronine-induced increments in target tissue $\beta$-adrenergic receptor densities is plausibly explained by the observed, apparently compensatory, increase in the insulin secretory response during epinephrine infusions, as noted previously by Perez et al. (18). The increased insulin secretory response to epinephrine in thyrotoxicosis could have been nonspecific, the result of increased $\beta_{2}$-adrenergic sensitivity (stimulatory), decreased $\alpha_{2}$-adrenergic sensitivity (inhibitory), or both of insulin secreting pancreatic $\beta$-cells. However, direct exposure of perfused pancreatic rat islets to triiodothyronine has been reported to decrease (35) or have no effect (36) on the insulin secretory response to glucose. Furthermore, in the present study there was not a generalized change in islet sensitivity to epinephrine since plasma glucagon levels were unchanged during thyrotoxicosis. Finally, the precise matching of the glucose, lactate, FFA, and $\beta$-hydroxybutyrate responses to epinephrine in vivo before and after triiodothyronine administration suggests feedback regulation of insulin secretion, i.e., that the enhanced insulin secretory response was a homeostatic regulatory event. Thus, we cannot conclude that it was the result of increased $\beta$-cell sensitivity to epinephrine per se.

With respect to the unaltered blood pressure and heart rate responses to epinephrine during thyrotoxicosis, one could speculate that enhanced $\beta$-adrenergic sensitivity was offset in part by augmented parasympathetic activity. We have no direct measure of the latter, but observed an increased plasma pancreatic polypeptide response to epinephrine during thyrotoxicosis. The plasma pancreatic polypeptide response to hypoglycemia is mediated by the parasympathetic nervous system; however, it is not clear whether or not the response to epinephrine $(37,38)$ is a marker of parasympathetic function.

In a related study in a larger group of normal subjects we found no relationships between mononuclear leukocyte $\left(\beta_{2}\right)$, platelet $\left(\alpha_{2}\right)$, fat cell $\left(\beta_{1}\right)$, and skeletal muscle $\left(\beta_{2}\right)$ adrenergic receptor densities or their corresponding basal, stimulated $(\beta)$, or inhibited $\left(\alpha_{2}\right)$ cAMP contents/adenylate cyclase activities, and metabolic or hemodynamic sensitivity to epinephrine in vivo (39). Thus, interindividual variation in adrenergic receptor densities and their linked adenylate cyclase systems is not sufficient to alter in vivo sensitivity to epinephrine, at least with respect to the endpoints assessed. As a direct corollary, measurements of these receptor/adenylate cyclase parameters do not appear predictive of the responses to the hormone in vivo. In the present study we found no effect of induced changes in catecholamine target tissue adrenergic receptor densities, documented here in fat and skeletal muscle and probably present in other tissues $(5,33,34)$, on the metabolic and hemodynamic responses to epinephrine in vivo. Again, these measurements were not predictive of the response to the hormone in vivo.

Obviously we cannot exclude the possibility that differences in adrenergic receptor densities of greater magnitude than we produced might result in altered sensitivity to epinephrine in vivo. However, reports of relationships between measured adrenergic receptors and in vivo responses to agonists have shown conflicting results (40-45). In view of the striking homeostatic efficiency of the intact individual demonstrated in the current study, the finding of altered adrenergic receptor characteristics, even in target tissues, should not be extrapolated to altered sensitivity to catecholamines in vivo. 
Rather, it should serve as the basis of a hypothesis that must then be tested in vivo before it is incorporated into concepts of regulatory physiology and pathophysiology.

Finally, with respect to the clinical issue, these data suggest that increased sensitivity to catecholamines does not explain clinical manifestations of thyrotoxicosis in humans. However, we emphasize that we studied normal humans before and during short-term, experimental thyrotoxicosis that clearly differed in duration, and may have differed in other important ways, from spontaneous thyrotoxicosis.

\section{Acknowledgments}

The authors acknowledge the technical assistance of Mr. Krishan Jethi, Ms. Alka Bansal, Mr. Geoffrey Boyd, Ms. Joy Brothers, Ms. Shirley Hill, Ms. Galina Leybovich, Ms. Zina Lubovich, and Mr. Abbey Akinola in performance of the hormone and metabolic intermediate assays, the assistance of the nursing staff, particularly Ms. Jane Mann, of the Washington University General Clinical Research Center, and the secretarial assistance of Ms. Mary Kharibian. We thank particularly Dr. Jay M. McDonald for advice concerning fat cell isolation.

This work was supported in part by National Institutes of Health grants DK-27085, DK-20579, and RR-00036.

\section{References}

1. Grossman, W., N. L. Rubin, and C. W. Johnson. 1971. The enhanced myocardial constractility of thyrotoxicosis. Ann. Intern. Med. 74:869-874.

2. Coulombe, P., J. H. Dussault, J. LeTarte, and S. J. Simard. 1976. Catecholamine metabolism in thyroid diseases. I. Epinephrine secretion rate in hyperthyroidism and hypothyroidism. J. Clin. Endocrinol. \& Metab. 42:125-130.

3. Coulombe, P., J. H. Dussault, and P. Walker. 1977. Catecholamine metabolism in thyroid disease. II. Norepinephrine secretion rate in hyperthyroidism and hypothyroidism. J. Clin. Endocrinol. \& Metab. 44:1185-1189.

4. Bilezikian, J. P., and J. N. Loeb. 1983. The influence of hyperthyroidism on $\alpha$-and $\beta$-adrenergic receptor systems and adrenergic responsiveness. Endocr. Rev. 4:378-388.

5. Ginsberg, A. M., W. E. Clutter, S. D. Shah, and P. E. Cryer. 1981. Triiodothyronine-induced thyrotoxicosis increases mononuclear leukocyte $\beta$-adrenergic receptor density in man. J. Clin. Invest. 67:1785-1791.

6. Anderson, R. G. G., O. R. Nilsson, and J. F. Kuo. 1983. $\beta$ adrenoceptor-adenosine 3',5'-monophosphate system in human leucocytes before and after treatment for hyperthyroidism. J. Clin. Endocrinol. \& Metab. 56:42-45.

7. Ratge, D., S. Hansel-Bessey, and H. Wisser. 1985. Altered Plasma catecholamines and numbers of $\alpha$ - and $\beta$-adrenergic receptors in platelets and leukocytes in hyperthyroid patients normalized under antithyroid treatment. Acta Endocrinol. 110:75-82.

8. Williams, R. S., C. E. Guthrow, and R. J. Lefkowitz. 1979. $\beta$-adrenergic receptors of human lymphocytes are unaltered by hyperthyroidism. J. Clin. Endocrinol. \& Metab. 48:503-505.

9. Smith, B. M., J. H. Silas, and R. O. Yates. 1981. Unaltered lymphocyte $\beta$-adrenergic responsiveness in hyperthyroidism and hypothyroidism. Clin. Pharmacol. Ther. 29:327-331.

10. Hui, K. K. P., R. N. Wolfe, and M. E. Conolly. 1981. Lymphocyte $\beta$-adrenergic receptors are not altered in hyperthyroidism. Clin. Pharmacol. Ther. 32:161-164.

11. Wahrenberg, H., P. Engfeldt, P. Arner, A. Wennlund, and J. Ostman. 1986. Adrenergic regulation of lipolysis in human adipocytes: findings in hyper- and hypothyroidism. J. Clin. Endocrinol. \& Metab. 63:631-638.
12. Richelsen, B., and N. S. Sorensen. 1987. $\alpha_{2}$ - and $\beta$-adrenergic receptor binding and action in gluteal adipocytes from patients with hypothyroidism and hyperthyroidism. Metab. Clin. Exp. 36:10311039.

13. Aoki, V. S., W. R. Wilson, and E. O. Theilen. 1972. Studies of the reputed augmentation of the cardiovascular effects of catecholamines in patients with spontaneous hyperthyroidism. J. Pharmacol. Exp. Ther. 181:362-368.

14. Aoki, V. S., W. R. Wilson, E. O. Theilen, W. W. Lukensmeyer, and P. E. Leaverton. 1967. The effects of triiodothyronine on hemodynamic responses to epinephrine and norephinephrine in man. J. Pharmacol. Exp. Ther. 157:62-68.

15. Guttler, R. V., J. W. Shaw, C. L. Otis, and J. T. Nicoloff. 1975. Epinephrine-induced alterations in urinary cyclic AMP in hyper- and hypothyroidism. J. Clin. Endocrinol. \& Metab. 41:707-711.

16. Gelfand, R. A., K. A. Hutchinson-Williams, A. A. Bonde, P. Castellino, and R. S. Sherwin. 1987. Catabolic effects of thyroid hormone excess: the contribution of adrenergic activity to hypermetabolism and protein breakdown. Metab. Clin. Exp. 36:562-569.

17. Harlan, W. R., J. Lazlo, M. D. Bogdonoff, and H. Estes. 1963. Alterations in free fatty acid metabolism in endocrine disorders. I. Effect of thyroid hormone. J. Clin. Endocrinol. \& Metab. 23:33-38.

18. Perez, G., B. Ungaro, A. Covelli, G. Morrone, G. Lombardi, F. Scopacasa, and R. Rossi. 1980. Altered glucoregulatory response to physiological infusions of epinephrine and glucagon in hyperthyroidism. J. Clin. Endocrinol. \& Metab. 51:972-977.

19. Clutter, W. E., R. A. Rizza, J. E. Gerich, and P. E. Cryer. 1988. Regulation of glucose metabolism by sympathochromaffin catecholamines. Diabetes Metab. Rev. 4:1-15.

20. Berk, M. A., W. E. Clutter, D. A. Skor, S. D. Shah, R. P. Gingerich, C. A. Parvin, and P. E. Cryer. 1985. Enhanced glycemic responsiveness to epinephrine in insulin-dependent diabetes mellitus is the result of the inability to secrete insulin. J. Clin. Invest. 75:18421851.

21. Lafontan, M., M. Berlan, and A. Villeneuve. 1983. Preponderance of $\alpha_{2}$ - over $\beta_{1}$-adrenergic receptor sites in human fat cells is not predictive of the lipolytic effect of physiological catecholamines. $J$. Lipid Res. 24:429-440.

22. Rodbell, M. 1964. Metabolism of isolated fat cells. J. Biol. Chem. 239:375-380.

23. Labarca, C., and K. Paigen. 1980. A simple, rapid, and sensitive DNA assay procedure. Anal. Biochem. 102:344-352.

24. Liggett, S. B., S. D. Shah, and P. E. Cryer. 1988. Characterization of $\beta$-adrenergic receptors of human skeletal muscle obtained by needle biopsy. Am. J. Physiol. 254:E795-E798.

25. Bradford, M. M. 1976. A rapid and sensitive method for the quantitation of microgram quantities of protein utilizing the principle of protein dye binding. Anal. Biochem. 72:248-259.

26. Doyle, V. M., F. R. Buhler, and E. Burgisser. 1984. Inappropriate correction for radioactive decay in fully iodinated adrenergic ligands. Eur. J. Pharmacol. 99:353-356.

27. Harder, J. F., and G. Brooker. 1975. Femtomole sensitivity radioimmunassay for cyclic AMP and cyclic GMP after 2' 0 acetylation by acetic anhydride in aqueous solution. J. Cyclic Nucleotide Res. 1:207-218.

28. Steiner, A. L., C. W. Parker, and D. M. Kipnis. 1972. Radioimmunoassay for cyclic nucleotides. J. Biol. Chem. 247:11061113.

29. Shah, S. D., W. E. Clutter, and P. E. Cryer. 1985. External and internal standards in the single isotope derivative (radioenzymatic) assay of plasma norepinephrine and epinephrine in normal humans and persons with diabetes mellitus or chronic renal failure. J. Lab. Clin. Med. 106:624-629.

30. Kennedy, F., V. Go, P. E. Cryer, G. Bolli, and J. Gerich. 1988. Subnormal pancreatic polypeptide and epinephrine responses to insulin-induced hypoglycemia identify patients with insulin dependent diabetes mellitus predisposed to develop autonomic neuropathy. Ann. Intern. Med. 108:54-58. 
31. Scatchard, G. 1949. The attractions of proteins for small molecules and ions. Ann. NY Acad. Sci. 51:660-672.

32. Staten, M. A., D. E. Matthews, P. E. Cryer, and D. M. Bier. 1987. Physiological increments in epinephrine stimulate metabolic rate in humans. Am. J. Physiol. 253:E322-E330.

33. Brodde, O.-E., R. Kretsch, K. Ikezono, H-R. Zerkowski, and J. G. Reidemeister. 1986. Human $\beta$-adrenoceptors: relation of myocardial and lymphocyte $\beta$-adrenergic density. Science (Wash. DC). 231:1584-1585.

34. Liggett, S. B., J. C. Marker, S. D. Shah, C. L. Roper, and P. E. Cryer. 1988. Direct relationship between mononuclear leukocyte and lung $\beta$-adrenergic receptors and apparent reciprocal relationship of extravascular, but not intravascular, $\alpha$ - and $\beta$-adrenergic receptors by the sympathochromaffin system in humans. J. Clin. Invest. 82:48-56.

35. Lenzen, S., U. Panten, and H. Masselblatt. 1975. Thyroxin treatment and insulin secretion in the rat. Diabetologia. 11:49-55.

36. Yamamoto, T., N. Takeda, T. Ashano, H. Sasaki, and $M$. Okumura. 1987. The effects of triiodothyronine $\left(\mathrm{T}_{3}\right)$ and thyroxine $\left(\mathrm{T}_{4}\right)$ upon insulin secretion from isolated rat pancreatic islets. Endocrinol. Jpn. 34:605-609.

37. Schwartz, T. W. 1983. Pancreatic polypeptide: a hormone under vagal control. Gastroenterology. 85:1411-1425.

38. Sive, A. A., A. I. Vinik, and N. Levitt. 1980. Adrenergic modulation of human pancreatic polypeptide release. Gastroenterology. 79:665-672.
39. Liggett, S. B., S. D. Shah, and P. E. Cryer. 1989. Human tissue adrenergic receptors are not predictive of responses to epinephrine in vivo. Am. J. Physiol. In press.

40. Fraser, J., J. Nadeau, D. Robertson, and A. J. J. Wood. 1981. Regulation of human leukocyte beta receptors by endogenous catecholamines. J. Clin. Invest. 67:1777-1784.

41. Martinsson, A., K. Larsson, and P. Hjemdahl. 1987. Studies in vivo and in vitro of terbutaline-induced $\beta$-adrenoceptor desensitization in healthy subjects. Clin. Sci. (Lond.). 72:47-54.

42. Tashkin, D. P., M. E. Conolly, R. I. Deutsch, K. K. Hui, M. Littner, P. Scarpace, and I. Abrass. 1982. Subsensitization of $\beta$-adrenoceptors in airways and lymphocytes of healthy and asthmatic subjects. Am. Rev. Respir. Dis. 125:185-193.

43. Busse, W. W., G. Sharpe, A. Smith, M. Arbabian, L. Borgen, and A. Rvoho. 1985. The effect of procaterol treatment on $\beta$-adrenergic bronchodilation and polymorphonuclear leukocyte responsiveness. Am. Rev. Respir. Dis. 132:1194-1198.

44. Bannister, R., A. W. Boylston, I. B. Davies, C. J. Mathias, P. S. Sever, and D. Sudera. 1981. $\beta$-receptor numbers and thermodynamics in denervation supersensitivity. J. Physiol. (Lond.). 319:369-377.

45. Bristow, M. R., R. Ginsburg, W. Minobe, R. S. Cubicciotti, W. S. Sageman, K. Lurie, M. E. Billingham, D. C. Harrison, and E. B. Stinson. 1982. Decreased catecholamine sensitivity and $\beta$-adrenergic receptor density in failing human hearts. N. Engl. J. Med. 307:205211. 